\title{
ANALISIS BUKU FISIKA SMA KELAS XII MATERI LISTRIK DINAMIS BERDASARKAN ASPEK KONSEPTUAL DAN PROSEDURAL
}

Hilarius Donatus Hun ${ }^{1}$, Fakhruddin ${ }^{2}$, dan Yusniati H.Muh. Yusuf ${ }^{3}$

${ }^{1}$ Mahasiswa Prodi Pendidikan Fisika Universitas Nusa Cendana, Kupang, Indonesia

${ }^{2,3}$ Dosen Prodi Pendidikan Fisika Universitas Nusa Cendana, Kupang, Indonesia

Email: aryhun37@gmail.com.

\section{Info Artikel}

Diterima:

16 Oktober 2019

Disetujui:

30 November 2019

Dipublikasikan:

15 Desember 2019

\begin{abstract}
Abstrak:
Penelitian ini bertujuan untuk mengetahui ketersediaan aspek pengetahuan konseptual dan pengetahuan prosedural dalam buku teks pelajaran fisika SMA kelas XII kurikulum 2013 pada materi pokok listrik dinamis. Penelitian ini mengunakan pendekatan kualitatif dengan jenis evaluatif. Penelitian dilaksanakan di SMA Negeri 2 Kupang, SMA Negeri 4 Kupang, SMA Negeri 5 Kupang, SMA Negeri 8 Kupang, dan MA Negeri Kupang. Hasil penelitian menunjukkan bahwa ketersediaan aspek pengetahuan konseptual pada buku teks A sebesar 59,03\% (kategori tinggi) dan buku teks B sebesar 60,43\% (kategori tinggi). Ketersediaan aspek pengetahuan prosedural pada buku teks A sebesar 13,89\% (kategori rendah) dan buku teks B sebesar sebesar 15,75\% (kategori rendah).
\end{abstract}

Kata kunci: Buku fisika, pengetahuan konseptual, pengetahuan prosedural

\begin{abstract}
:
This research aims to determine the availability of aspects of conceptual knowledge and procedural knowledge in the textbooks of high school physics class XII curriculum 2013 on dynamic electrical staple material. This study uses a qualitative approach with evaluative types. The study was conducted at SMA Negeri 2 Kupang, SMA Negeri 4 Kupang, SMA Negeri 5 Kupang, SMA Negeri 8 Kupang, and MA Negeri Kupang. The results showed that the availability of conceptual knowledge in textbooks A amounted to $59.03 \%$ (High category) and textbook $B$ of $60.43 \%$ (High category). The availability of A procedural knowledge aspect of textbook $A$ is $13.89 \%$ (Low category) and textbook B of $15.75 \%$ (Low category).
\end{abstract}

Keywords: Physics textbooks, conceptual knowledge, prosedural knowledge 


\section{Pendahuluan}

Undang-undang No 20 Tahun 2003 tentang Sisdiknas menyatakan bahwa pembelajaran adalah proses interaksi peserta didik dengan pendidik dan sumber belajar pada suatu lingkungan belajar. Komponen pembelajaran terdiri dari : tujuan pembelajaran, materi pembelajaran, kegiatan pembelajaran, metode, media/alat, dan evaluasi. Buku teks pelajaran berfungsi sebagai pedoman manual bagi peserta didik dalam belajar dan bagi guru dalam membelajarkan peserta didik untuk bidang studi atau mata pelajaran (Sitepu, 2012:20-21). Oleh karena itu, buku sebagai salah satu komponen pembelajaran dari media pembelajaran memilki peran penting dalam efektifitas pembelajaran. Kehadiran buku dalam bentuk cetakan maupun elektronik telah memberikan pengaruh besar dalam proses belajar dan membelajarkan sehingga menimbulkan revolusi dalam pendidikan. Salah satu aspek penilaian buku teks pelajaran fisika yang ditetapkan oleh BSNP yaitu kelayakan isi. Dalam kelayakan isi pada bagian dimensi pengetahuan BSNP menetapkan bahwa buku teks pelajaran fisika yang baik harus menyajikan konsep yang tidak menimbulkan banyak multitafsir dan sesuai dengan definisi yang berlaku dalam ilmu fisika dan prosedur/metode yang dapat diterapkan dengan runtut dan benar. Hal ini menunjukkan bahwa buku teks pelajaran fisika harus mengandung pengetahuan konseptual dan pengetahuan prosedural.

Selama ini, penelitian tentang pengetahuan konseptual dan prosedural sudah banyak dilakukan. Namun, penelitian-penelitian yang ada hanya dilakukan dalam proses pembelajaran berupa mengukur besarnya pengetahuan konseptual dan prosedural yang dimilki oleh peserta didik. Misalnya seperti penelitian yang dilakukan oleh Khamidah (2017) tentang "Pemahaman Konseptual dan Pengetahuan Prosedural Siswa Kelas VIII dalam Penyelesaian Soal Matematika pada Materi Sistem Persamaan Linier Dua Variabel". Hasil penelitiannya menunjukkan bahwa kemampuan konseptual dan prosedural peserta didik masih rendah. Hal ini menunjukkan bahwa perlu adanya pengkajian untuk mengetahui ketersedian pengetahuan konseptual dan prosedural dalam buku-buku teks pelajaran yang digunakan peserta didik dan guru di sekolah.

Menurut Brockhaus (Druxes, 1986:3) fisika adalah pelajaran tentang kejadian di alam yang memungkinkan penelitian dengan percobaan, pengukuran apa yang didapat, penyajian secara matematis, dan berdasarkan peraturan-peraturan umum. Hal ini berarti bahwa proses pembelajaran fisika menekan pada pemberian pengalaman langsung untuk mengembangkan kompetensi peserta didik agar menjelajahi dan memahami alam sekitar secara ilmiah. Hal ini berarti bahwa proses pembelajaran fisika menekan pada pemberian pengalaman langsung untuk mengembangkan kompetensi peserta didik agar menjelajahi dan memahami alam sekitar secara ilmiah.

Tuntutan dalam pembelajaran fisika mempengaruhi jenis dan karakter dari kurikulum yang harus digunakan agar tujuan pembelajaran yang diinginkan dapat tercapai. Di Indonesia saat ini, menerapkan kurikulum 2013 dengan pendekatan saintifik yang mengadopsi langkah-langkah ilmuan dalam membangun pengetahuan. K-13 memilki ciri utama student center artinya pembelajaran berpusat pada peserta didik sehingga peserta didik dituntut aktif, disiplin, dan mandiri dalam mencari ilmu pengetahuan, layaknya yang dilakukan oleh para ilmuan.

Salah satu materi fisika yang memang membutuhkan penekanan pada konsep dan eksperimen atau percobaan adalah listrik dinamis. Dalam mempelajari listrik dinamis banyak konsep yang membutuhkan eksperimen agar konsep fisika tersebut dapat tersampaikan dan dimengerti dengan baik oleh peserta didik, contohnya seperti hukum Ohm dan hukum Kirchoff. Hal ini menunjukkan bahwa buku yang digunakan pešerta didik perlu menyediakan aspek pengetahuan konseptual dan aspek pengetahuan prosedural.

Penelitian analisis buku teks pelajaran sudah mulai banyak dilakukan, namun penelitian sebelumnya mengenai analisis buku teks pelajaran berdasarkan aspek pengetahuan konseptual dan aspek pengetahuan prosedural belum banyak dilakukan. Pada penelitian sebelumnya penelitian analisis buku teks pelajaran hanya dilakukan berdasarkan aspek Keterampilan Generik Sains (KGS) misalnya 
penelitian yang dilakukan oleh Iriani (2016), literasi sains misalnya penelitian yang dilakukan oleh Maturradiyah \& Rusilawati (2015), Keterampilan Proses Sains (KPS) misalnya penelitian yang dilakukan oleh Rahayu (2017), dan miskonsepsi misalnya penelitian yang dilakukan oleh Respatiningrum, Radiyono, dan Wiyono (2015).

Pada penelitian ini, peneliti akan melakukan analisis materi pembelajaran berdasarkan aspek pengetahuan konseptual dan aspek pengetahuan prosedural pada kurikulum 2013. Belum diketahuinya ketersediaan aspek pengetahuan konseptual dan aspek pengetahuan prosedural dalam buku teks pelajaran kurikulum 2013 menjadi alasan peneliti melakukan penelitian ini. Pengembangan aspek pengetahuan konseptual dan aspek pengetahuan prosedural dalam buku teks pelajaran yang digunakan dapat mengasah kemampuan peserta didik agar dapat menghubungkan masalah yang Ia temukan sehari-hari dengan rangkaian ideide yang telah dipelajarinya sehingga Ia mampu menerangkan dan memberi makna pada prosedur yang akan digunakan untuk menyelesaikan masalah tersebut .

\section{Metode Penelitian}

Penelitian ini termasuk ke dalam penelitian deskriptif. Penelitian ini mendeskripsikan ketersedian aspek pengetahuan konseptual dan aspek pengetahuan prosedural pada materi listrik dinamis. Penelitian ini dilaksanakan di lima Sekolah, yakni SMAN 2 Kupang, SMAN 4 Kupang, SMAN 5 Kupang, dan SMAN 8 Kupang dan satu MA, yakni MAN Kupang pada tanggal 2224 Juli 2019.

Subjek penelitian ini adalah materi listrik dinamis yang terdapat dalam buku teks pelajaran fisika kelas XII K-13. Untuk menentukan jenis buku teks pelajaran yang diteliti maka peneliti mengambil sampel buku teks pelajaran yang digunakan di empat SMA Negeri dan satu MA Negeri di Kota Kupang. Namun tidak semua buku teks pelajaran diteliti. Buku teks pelajaran yang diteliti dipilih dari dua buku terbanyak yang ditemukan pada lima sekolah yang dikunjungi. Hanya dua buku teks pelajaran yang dipilih karena dianggap mewakili buku terbaik yang tersebar di lima sekolah yang diteliti dan mewakili populasi penelitian. Objek penelitian ini adalah presentase ketersedian pengetahuan konseptual dan pengetahuan prosedural.

Langkah awal penelitian ini adalah menyusun instrumen yang akan digunakan di dalam penelitian. Setelah itu instrumen divalidasi dengan menggunakan validasi konstruk. Setelah instrumen siap untuk digunakan peneliti mengunjungi lima sekolah yang telah dipilih karena berakreditasi A dan telah menggunakan K-13. Di setiap sekolah peneliti mewawancarai guru fisika kelas XII untuk mengetahui buku teks pelajaran apa yang digunakan. Berdasarkan informasi yang diperoleh peneliti kemudian menentukan dua buku teks pelajaran fisika yang paling banyak digunakan dari kelima sekolah yang diteliti. Dua buku teks pelajaran fisika yang telah dipilih kemudian dianalisis dengan menggunakan instrumen yang telah dibuat. Analisisnya berupa mengecek ketersediaan pengetahuan konseptual dan pengetahuan prosedural pada setiap kalmat di dalam buku teks pelajaran fisika yang diteliti. Hasil analisis kemudian dibuat dalam bentuk presentase.

Data yang dikumpulkan adalah data kualitatif berupa materi listrik dinamis yang terdapat di dalam buku teks pelajaran fisika kelas XII K-13. Untuk mendapatkan data ini digunakan tiga teknik pengumpulan data yaitu wawancara, angket, dan observasi. Wawancara dilakukan untuk dapat menentukan jenis buku teks pelajaran fisika yang akan diteliti. Angket ini berisi daftar pertanyaan yang akan diisi oleh responden yaitu guru fisika SMA kelas XII. Pada penelitian ini peneliti mengobservasi buku teks pelajaran fisika kelas XII K-13 dengan menggunakan lembar observasi. Lembar obsevaasi berisikan nomor, kode, pernyataan, subjenis pengetahuan, dan penjelasan. Lembar observasi digunakan untuk menentukan ketersediaan pengetahuan konseptual dan pengetahuan prosedural pada buku teks pelajaran fisika yang diteliti.

Data hasil penelitian dibuat dalam bentuk presentase. Kemudian presentase ketersediaan pengetahuan konseptual dan pengetahuan prosedural dikategorikan dengan menggunakan instrumen penilaian buku yang dikeluarkan BSNP sebagai berikut.

Tabel 1 Kategori Penilaian Buku Teks Pelajaran

\begin{tabular}{|l|l|l|}
\hline No & Presentase $(\mathbf{x})$ & Kategori \\
\hline 1 & $\mathrm{x} \leq 25 \%$ & Rendah \\
\hline 2 & $25 \%<\mathrm{x} \leq 50 \%$ & Cukup \\
\hline 3 & $50 \%<\mathrm{x} \leq 75 \%$ & Tinggi \\
\hline
\end{tabular}




\begin{tabular}{|l|l|l|}
\hline 4 & $75 \%<\mathrm{x} \leq 100 \%$ & Sangat Tinggi \\
\hline
\end{tabular}

(sumber: BSNP, 2010 dalam Pujiastuti, 2013)

\section{Hasil dan Pembahasan}

Wawancara dilaksanakan pada tanggal 22-24 juli 2019. Hasil wawancara pada lima sekolah mengenai jenis buku yang digunakan ditampilkan pada Tabel 2. Berdasarkan Tabel 2, dapat dilihat bahwa jenis buku teks pelajaran fisika yang tersebar di SMA Negeri di Kota Kupang bervariasi dari penerbit Erlangga, Grafindo, dan platinum dengan kurikulum yang digunakan yaitu K-13. Meskipun demikian ada beberapa sekolah yang menyatakan bahwa dalam proses pembelajaran mereka masih menggunakan buku teks pelajaran fisika KTSP. Hal ini dikarenakan walaupun sekolah mereka sudah menerapkan K-13, ketersedian bukubuku K-13 masih sangat kurang sehingga mereka masih harus menggunakan buku teks pelajaran fisika KTSP.

Pada awalnya penelitian ini ingin membandingkan antara buku teks pelajaran yang diterbitkan swasta dengan buku teks pelajaran yang diterbitkan pemerintah (BSE). Namun dari hasil penelitian di lima sekolah diperoleh hasil bahwa buku BSE hanya tersedia dalam bentuk KTSP. Karena fokus penelitian ini pada kurikulum K-13 maka akhirnya peneliti memilih untuk membandingkan dua buku teks pelajaran fisika terbanyak yang digunakan di lima sekolah yang menjadi tempat penelitian.

Tabel 2. Hasil Wawancara

\begin{tabular}{|c|c|c|}
\hline $\begin{array}{c}\text { ama } \\
\text { Sekolah }\end{array}$ & $\begin{array}{l}\text { Buku } \\
\text { Wajib }\end{array}$ & $\begin{array}{c}\text { ku } \\
\text { Tambahan }\end{array}$ \\
\hline $\begin{array}{ll}\text { SMAN } & 2 \\
\text { Kupang } & \end{array}$ & $\begin{array}{lr}\text { Buku } & \text { teks } \\
\text { pelajaran } & \text { fisika } \\
\text { yang } & \text { ditulis } \\
\text { Marthen } & \text { Kanginan } \\
\text { penerbit } & \text { Erlangga } \\
\text { K-13 } & \end{array}$ & $\begin{array}{l}\text { Buku teks } \\
\text { pelajaran } \\
\text { fisika yang } \\
\text { ditulis Ketut } \\
\text { Kamayaja } \\
\text { dan Wawan } \\
\text { Purnama } \\
\text { penerbit } \\
\text { Grafindo K- } \\
13\end{array}$ \\
\hline $\begin{array}{ll}\text { SMAN } & 4 \\
\text { Kupang } & \end{array}$ & $\begin{array}{lr}\text { Buku } & \text { teks } \\
\text { pelajaran } & \text { fisika } \\
\text { yang } & \text { ditulis } \\
\text { Marthen } & \text { Kanginan } \\
\text { penerbit } & \text { Erlangga } \\
\text { K-13 } & \end{array}$ & $\begin{array}{l}\text { Buku teks } \\
\text { pelajaran } \\
\text { fisika yang } \\
\text { ditulis } \\
\text { Yohanes } \\
\text { Surya dan } \\
\text { Buku teks } \\
\text { pelajaran } \\
\text { fisika }\end{array}$ \\
\hline
\end{tabular}

\begin{tabular}{|c|c|c|}
\hline & & penerbit lain \\
\hline $\begin{array}{l}\text { SMAN } \\
\text { Kupang }\end{array}$ & $\begin{array}{lr}\text { Buku } & \text { teks } \\
\text { pelajaran } & \text { fisika } \\
\text { yang ditulis } & \text { Ketut } \\
\text { Kamayaja } & \text { dan } \\
\text { Wawan } & \text { Purnama } \\
\text { penerbit } & \text { Grafindo } \\
\text { K-13 } & \end{array}$ & $\begin{array}{l}\text { Buku-buku } \\
\text { teks } \\
\text { pelajaran } \\
\text { fisika KTSP }\end{array}$ \\
\hline $\begin{array}{ll}\text { SMAN } & 8 \\
\text { Kupang } & \end{array}$ & $\begin{array}{lr}\text { Buku } & \text { teks } \\
\text { pelajaran } & \text { fisika } \\
\text { yang ditulis } & \text { Ketut } \\
\text { Kamayaja } & \text { dan } \\
\text { Wawan } & \text { Purnama } \\
\text { penerbit } & \text { Grafindo } \\
\text { K-13 } & \\
\end{array}$ & $\begin{array}{l}\text { Buku-buku } \\
\text { teks } \\
\text { pelajaran } \\
\text { fisika KTSP }\end{array}$ \\
\hline $\begin{array}{l}\text { MAN } \\
\text { Kupang }\end{array}$ & 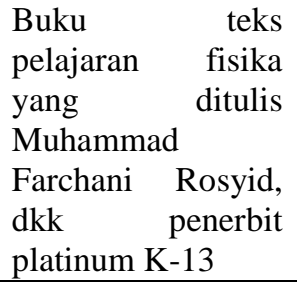 & $\begin{array}{l}\text { Buku-buku } \\
\text { teks } \\
\text { pelajaran } \\
\text { fisika KTSP }\end{array}$ \\
\hline
\end{tabular}

Berdasarkan Tabel 2, dapat dilihat bahwa dua buku teks pelajaran fisika K-13 yang paling banyak digunakan adalah buku teks pelajaran yang ditulis oleh Kamajaya dan Purnama tahun 2016 dan buku teks pelajaran yang ditulis Kanginan tahun 2018. Kedua buku teks pelajaran dianalisis menggunakan instrumen yang telah dirumuskan. Buku teks pelajaran yang ditulis oleh Kamajaya dan Purnama tahun 2016 dikodekan dengan nama buku teks pelajaran I sedangkan buku teks pelajaran yang ditulis Kanginan tahun 2018 dikodekan dengan nama buku teks pelajaran II. Hasil analisis yang diperoleh berupa frekuensi kemunculan subjenis pengetahuan pada masing-masing bagian buku teks pelajaran. Kemudian ketersediaan pengetahuan konseptual dan pengetahuan prosedural dalam kedua buku teks pelajaran dinyatakan dalam persentase. Berikut ini ditampilkan hasil analisis buku teks pelajaran I

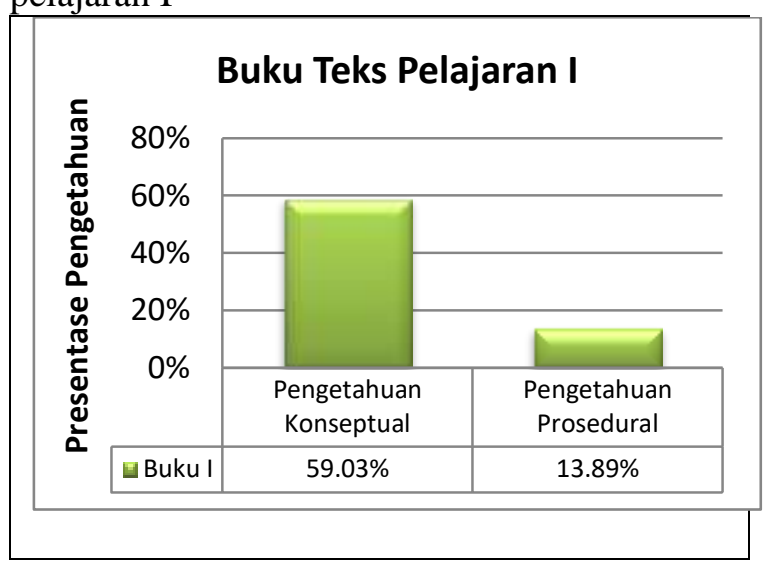




\section{Gambar 1. presentase pengetahuan konseptual dan pengetahuan prosedural pada buku teks pelajaran I}

Berdasarkan Gambar 1 secara

keseluruhan dapat dilihat bahwa pada buku teks pelajaran I ketersediaan pengetahuan konseptual lebih banyak daripada ketersediaan pengetahuan prosedural. Hal ini dapat terjadi karena dari keempat bagian buku yang dianalisis, subjenis pengetahuan 2 selalu tersedia dengan presentase yang jauh lebih tinggi dari kelima subjenis pengetahuan lainnya sehingga mempengaruhi secara signifikan presentase ketersediaan pengetahuan konseptual pada buku teks pelajaran I.

Berikut ini ditampilkan hasil analisis buku teks pelajaran II. Berdasarkan Gambar 2 secara keseluruhan dapat dilihat bahwa pada buku teks pelajaran II ketersediaan pengetahuan konseptual lebih banyak daripada ketersediaan pengetahuan prosedural. Hal ini dapat terjadi karena dari keempat bagian buku yang dianalisis, subjenis pengetahuan konseptual selalu tersedia dan subjenis pengetahuan 2 muncul pada bagian penjelasan, contoh soal, dan latihan soal dengan presentase yang jauh lebih tinggi dari kelima subjenis pengetahuan lainnya sehingga mempengaruhi secara signifikan presentase ketersediaan pengetahuan konseptual pada buku teks pelajaran I.

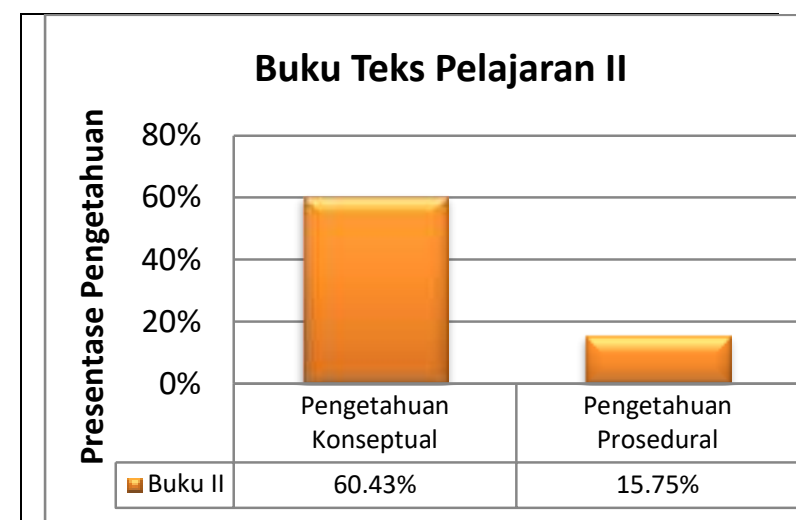

Gambar 2 presentase pengetahuan konseptual dan pengetahuan prosedural pada buku teks pelajaran II

Perbedaan cakupan materi pada buku teks pelajaran I dan buku teks pelajaran II ditampilkan pada Tabel 3 berikut ini:

\begin{tabular}{|l|l|l|l|}
\hline No & $\begin{array}{l}\text { Silabus materi } \\
\text { listrik dinamis }\end{array}$ & $\begin{array}{l}\text { Penambahan } \\
\text { pada buku } \\
\text { teks }\end{array}$ & $\begin{array}{l}\text { Penambahan } \\
\text { pada buku } \\
\text { teks } \\
\text { pelajaran I }\end{array}$ \\
pelajaran II \\
\hline
\end{tabular}

\begin{tabular}{|c|c|c|c|}
\hline 1 & $\begin{array}{l}\text { Arus listrik dan } \\
\text { pengukurannya }\end{array}$ & \multirow{8}{*}{\begin{tabular}{|l|} 
Hukum I \\
Kirchhoff \\
- Aplikasi \\
listrik \\
dinamis \\
- Rangkaian \\
Jembatan \\
Wheatston \\
e, \\
- Rangkaian \\
bantalan \\
hambatan
\end{tabular}} & \multirow{8}{*}{$\begin{array}{l}\text { - Hukum I } \\
\text { Kirchhoff } \\
\text { - Aplikasi } \\
\text { listrik } \\
\text { dinamis }\end{array}$} \\
\hline 2 & Hukum ohm & & \\
\hline 3 & $\begin{array}{l}\text { Arus listrik } \\
\text { dalam rangkaian } \\
\text { tertutup }\end{array}$ & & \\
\hline 4 & $\begin{array}{l}\text { Hambatan } \\
\text { sepotong kawat } \\
\text { penghantar }\end{array}$ & & \\
\hline 5 & $\begin{array}{l}\text { Rangkaian } \\
\text { hambatan }\end{array}$ & & \\
\hline 6 & $\begin{array}{l}\text { Gabungan } \\
\text { sumber } \\
\text { tegangan listrik }\end{array}$ & & \\
\hline 7 & $\begin{array}{ll}\text { Hukum } & \text { II } \\
\text { Kirchhoff } & \\
\end{array}$ & & \\
\hline & $\begin{array}{l}\text { Energi dan daya } \\
\text { listrik }\end{array}$ & & \\
\hline
\end{tabular}

Kedua buku teks pelajaran yang dianalisis merupakan buku teks pelajaran yang telah menggunakan kurikulum 2013 edisi revisi tahun 2016. Judul bab pada materi yang dianalisis dari kedua buku teks pelajaran sama, yaitu Rangkaian Arus Searah. Perbedaan mulai tampak dari permulaan kedua buku teks pelajaran. Pada buku teks pelajaran I dimulai dengan pemaparan tujuan pembelajaran sedangkan pada buku teks pelajaran II dimulai dengan pemaparan tujuan pembelajaran dan karakter yang ingin dikembangkan. Kemudian berlanjut pada peta konsep masing-masing buku teks pelajaran. Pada buku teks pelajaran I, peta konsepnya mengalir dalam satu arah dan menggambarkan secara runtut dan rinci kaitan antara komponen materi pelajaran dalam buku teks sedangkan Pada buku teks pelajaran I, peta konsepnya mengalir dalam dan arah dan hanya menggambarkan secara umum kaitan antara komponen materi pelajaran dalam buku teks.

Pada bagian penjelasan baik buku teks pelajaran I maupun buku teks pelajaran II penjelasan setiap submateri diawali dengan sebuah percobaan. Hanya saja pada buku teks pelajaran I setiap persamaan yang ditulis tidak diberikan penjabarannya. Berbeda dengan buku teks pelajaran II yang penjabaran yang detai mengenai dari mana persamaan tersebut berasal. Hal lainnya adalah untuk materi arus listrik dan pengukurannya pada buku teks pelajaran II, dijelaskan secara lengkap tentang konsep arus listrik, cara pengukuran arus listrik dan tegangan listrik menggunakan alat ukurnya masing-masing, dan cara melaporkan hasil pengukuran menggunakan kedua alat ukur tersebut. Pada buku teks pelajaran I, tidak 
dijelaskan cara penggunan alat ukur arus listrik dan tegangan listrik. Buku teks pelajaran I hanya menampilkan alat ukurnya dan cara alat ukur tersebut bekerja.

Pada bagian kegiatan peserta didik terdapat perbedaan antara buku teks pelajaran I dan buku teks pelajaran II. Pada buku teks pelajaran I ada dua jenis, yaitu kegiatan dan aktivitas ilmiah. Kegiatan berisi daftar pertanyaan untuk Pada buku teks pelajaran II hanya ada kegiatan. Kegiatan yang dilakukan bukan hanya berisi percobaan tetapi juga ada kegiatan menulis dan kegiatan mengamati.

Pada bagian contoh soal terdapat perbedaan antara buku teks pelajaran I dan buku teks pelajaran II. Pada buku teks pelajaran I, setiap submateri diberikan contoh soal kecuali pada submateri energi dan daya listrik serta aplikasi listrik DC. Pada buku teks pelajaran II, setiap submateri diberikan contoh soal kecuali pada submateri hukum ohm. Contoh-contoh soal yang diberikan pada buku teks pelajaran I kebanyakan mengarah pada soal tingkat mengaplikasikan (C3) sedangkan buku teks pelajaran II kebanyakan mengarah pada soal tingkat menganalisis (C4). Salah satu contoh soal tipe $\mathrm{C} 3$ pada buku teks pelajaran I dan salah satu contoh soal tipe C4 pada buku teks pelajaran II dapat dilihat pada Gambar 3 berikut ini.

\section{Contoh Soal Tipe C3}

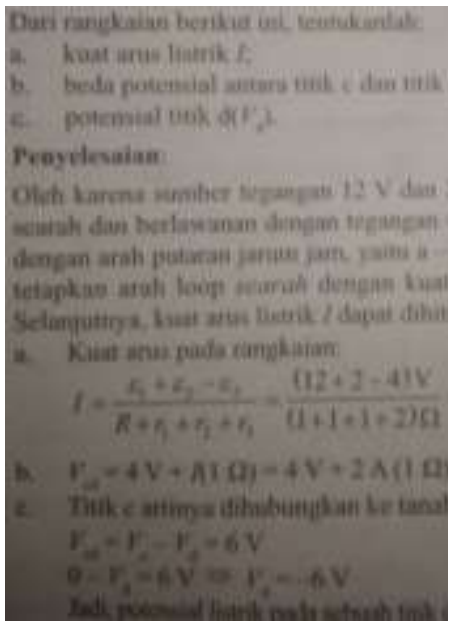

Contoh Soal Tipe C4

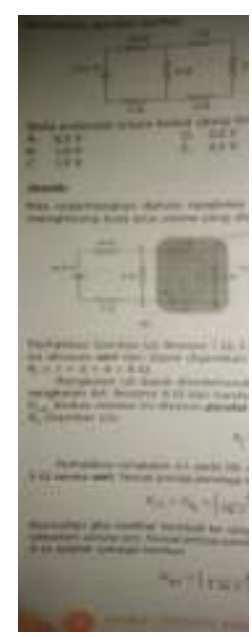

Gambar 3 Contoh soal pada materi Hukum I Kirchhoff

Pada bagian latihan soal terdapat perbedaan antara buku teks pelajaran I dan buku teks pelajaran II. Pada buku teks pelajaran I latihan soalnya terdiri atas: uji kompetensi awal yang berupa tes kemampuan awal sebagai prasyarat untuk mempelajari materi, tugas yang berupa pertanyaan tambahan untuk mengali sebuah submateri namun tugas tidak terdapat pada semua submateri, uji kompetensi yang berupa pertanyaan tentang sebuah submateri namun uji kompetensi tidak terdapat pada semua submateri, tugas proyek yang berupa tugas kelompok untuk membuat suatu produk, serta pilihan ganda dan esai yang memuat semua submateri.

Sedangkan pada buku teks pelajaran I latihan soalnya terdiri atas: Ayo cek kemampuan prasyarat yang berupa tes kemampuan awal sebagai prasyarat untuk mempelajari materi, kuis yang pertanyaanpertanyaan untuk menguji pemahaman konsep dalam menjawab soal dan kreativitas berpikir dari peserta didik, diskusi yang berupa pertanyaan tentang sebuah submateri namun diskusi tidak terdapat pada semua submateri, tugas proyek yang berupa tugas kelompok untuk membuat suatu produk, tugas portofolio yang berupa tugas individu untuk membuat rangkuman mengenai materi yang dipelajari, serta pilihan ganda dan esai yang memuat semua submateri.

Pada bagian ini akan dijelaskan mengenai data presentase ketersediaan pengetahuan konseptual dan pengetahuan prosedural pada empat bagian buku teks pelajaran yang dianalisis baik untuk buku teks pelajaran I maupun buku teks pelajaran II.

1. Penjelasan

Pada bagian ini baik untuk buku teks pelajaran I maupun buku teks pelajaran II ketersediaan pengetahuan konseptual lebih banyak daripada pengetahuan prosedural. Hal ini berarti baik penulis buku teks pelajaran I maupun penulis buku teks pelajaran II memilki fokus yang sama untuk memberikan perhatian lebih pada aspek konsep dan teori. Ketersediaan pengetahuan konseptual pada buku teks pelajaran I berada dalam kategori tinggi dan buku teks pelajaran II berada dalam kategori cukup. Sedangkan untuk pengetahuan prosedural baik untuk pada buku teks pelajaran I maupun buku teks pelajaran II berada dalam kategori rendah.

Pada bagian ini pengetahuan konseptual pada buku teks pelajaran I lebih banyak daripada pengetahuan konseptual pada buku teks pelajaran II karena jumlah cakupan materi pada buku teks pelajaran I lebih banyak 
daripada buku teks pelajaran II walaupun penjabaran persamaan-persamaan dalam buku teks pelajaran II lebih rinci daripada buku teks pelajaran I. Dengan jumlah materi yang lebih banyak, pernyataan-pernyataan dalam buku teks pelajaran I banyak yang mengarah pada pengetahuan tentang kesimpulan dan pengetahuan tentang sebuah konsep sehingga mempengaruhi secara signifikan presentase ketersediaan pengetahuan konseptual pada buku teks pelajaran I.

Untuk pengetahuan prosedural pada buku teks pelajaran II lebih banyak daripada buku teks pelajaran I. Hal ini karena penyajian materi pada buku teks pelajaran II banyak berupa kalimat-kalimat yang bersifat mengarahkan untuk melakukan sesuatu. Hal ini berkaitan dengan pengetahuan tentang prosedur untuk melakukan sesuatu sehingga mempengaruhi secara signifikan presentase ketersediaan pengetahuan prosedural pada buku teks pelajaran II.

2. Kegiatan Peserta Didik

Pada bagian ini terdapat perbedaan presentase antara buku teks pelajaran I dan buku teks pelajaran II. Pada buku teks pelajaran I ketersediaan pengetahuan konseptual lebih banyak daripada pengetahuan prosedural sedangkan pada buku teks pelajaran II ketersediaan pengetahuan prosedural lebih banyak daripada pengetahuan konseptual. Ketersediaan pengetahuan konseptual pada buku teks pelajaran I berada dalam kategori cukup dan buku teks pelajaran II berada dalam kategori rendah. Sedangkan untuk pengetahuan prosedural baik untuk pada buku teks pelajaran I maupun buku teks pelajaran II berada dalam kategori cukup.

Pada buku teks pelajaran I ketersediaan pengetahuan konseptual lebih banyak daripada pengetahuan prosedural karena pada bagian kegiatan peserta didik dibagi menjadi dua dengan nama: kegiatan dan aktivitas ilmiah. Pada bagian aktivitas ilmiah berisi penuh dengan pertanyaan untuk menguji pemahaman ko nseptual peserta didik sedangkan pada bagian kegiatan sebagian berisi kegiatan praktikum yang harus dilakukan dan sebagian berisi pertanyaan. Sedangkan pada buku teks pelajaran II kegiatan peserta didik berisi kegiatan praktikum, menulis, dan mengamati yang semuanya lebih banyak mengarah kepada pengetahuan prosedural. Dengan demikian wajar jika pengetahuan prosedural pada buku teks pelajaran II lebih dominan dari pengetahuan konseptualnya. Lebih lanjut dapat ditafsirkan bahwa penulis buku teks pelajaran I mempunyai fokus lebih kepada pengetahuan konseptual. Sedangkan penulis buku teks pelajaran II mempunyai fokus lebih kepada pengetahuan prosedural.

1. Contoh Soal

Pada bagian ini baik untuk buku teks pelajaran I maupun buku teks pelajaran II ketersediaan pengetahuan konseptual lebih banyak daripada pengetahuan prosedural. Hal ini berarti baik penulis buku teks pelajaran I maupun penulis buku teks pelajaran II memilki fokus yang sama untuk memberikan perhatian lebih pada soal mengenai aspek konsep dan teori. Ketersediaan pengetahuan konseptual pada buku teks pelajaran I berada dalam kategori tinggi dan buku teks pelajaran II berada dalam kategori sangat tinggi. Sedangkan untuk pengetahuan prosedural baik untuk pada buku teks pelajaran I maupun buku teks pelajaran II berada dalam kategori cukup.

Pada bagian ini pengetahuan konseptual pada buku teks pelajaran II lebih banyak daripada pengetahuan konseptual pada buku teks pelajaran I karena jumlah contoh soal pada buku teks pelajaran II lebih banyak daripada buku teks pelajaran I. Dengan jumlah contoh soal yang lebih banyak, pertanyaan contoh soal dalam buku teks pelajaran II banyak yang mengarah pada pengujian pengetahuan tentang sebuah konsep. Subjenis pengetahuan tentang prinsip dan generalisasi inilah yang mempengaruhi secara signifikan presentase ketersediaan pengetahuan konseptual pada buku teks pelajaran I.

Untuk pengetahuan prosedural pada buku teks pelajaran II juga lebih banyak daripada buku teks pelajaran I. Hal ini karena setiap contoh soal yang diberikan pada buku teks pelajaran II disertai dengan prosedur yang runtut untuk menyelesaikan soal. Hal ini karena pengetahuan prosedural juga berkaitan dengan pengetahuan tentang algoritme untuk menyelesaikan soal. Subjenis pengetahuan tentang keterampilan dalam bidang tertentu dan algoritme inilah yang mempengaruhi secara signifikan presentase ketersediaan pengetahuan prosedural pada buku teks pelajaran II.

\section{Latihan Soal}

Pada bagian ini baik untuk buku teks pelajaran I maupun buku teks pelajaran II 
ketersediaan pengetahuan konseptual lebih banyak daripada pengetahuan prosedural. Hal ini berarti baik penulis buku teks pelajaran I maupun penulis buku teks pelajaran II memilki fokus yang sama untuk menguji pemahaman peserta didik mengenai aspek konsep dan teori. Ketersediaan pengetahuan konseptual pada buku teks pelajaran I berada dalam kategori tinggi dan buku teks pelajaran II berada dalam kategori sangat tinggi. Sedangkan untuk pengetahuan prosedural pada buku teks pelajaran I berada dalam kategori rendah. Pengetahuan prosedural pada buku teks pelajaran II tidak tersedia sama sekali dalam bagian ini. Hal ini karena pada buku teks pelajaran II tidak terdapat soal yang menguji pemahaman peserta didik tentang pengetahuan prosedural.

Pada bagian ini pengetahuan konseptual pada buku teks pelajaran II lebih banyak daripada pengetahuan konseptual pada buku teks pelajaran I karena jumlah soal pada buku teks pelajaran II lebih banyak daripada buku teks pelajaran I. Dengan jumlah soal yang lebih banyak, pertanyaan soal dalam buku teks pelajaran II banyak yang mengarah pada pengujian pengetahuan peserta didik tentang setiap konsep yang telah disajikan pada buku. Subjenis pengetahuan tentang prinsip dan generalisasi inilah yang mempengaruhi secara signifikan presentase ketersediaan pengetahuan konseptual pada buku teks pelajaran II.

Dapat dilihat bahwa pengetahuan konseptual maupun pengetahuan prosedural pada buku teks pelajaran II lebih tinggi dari pengetahuan konseptual maupun pengetahuan prosedural pada buku teks pelajaran I. Hal ini dapat terjadi karena jumlah pernyataan dan pertanyaan yang dianalisis dari buku teks pelajaran II lebih sedikit daripada buku teks pelajaran I. Kemudian presentase pengetahuan konseptual dan pengetahuan prosedural pada tiap bagian buku teks pelajaran II lebih besar daripada buku teks pelajaran I. Dengan demikian jumlah pernyataan dan pertanyaan yang mengandung pengetahuan konseptual dan pengetahuan prosedural pada tiap bagian buku teks pelajaran II lebih banyak daripada buku teks pelajaran I.

Dapat lihat juga bahwa pada buku teks pelajaran I maupun buku teks pelajaran II presentase pengetahuan konseptual lebih tinggi dari presentase pengetahuan prosedural. Hal ini berarti bahwa penulis buku teks pelajaran I maupun buku teks pelajaran II sama-sama memfokuskan perhatian lebih pada aspek pengetahuan konseptual ketimbang aspek pengetahuan prosedural. Pemikiran kedua penulis ini tepat karena buku yang mereka tulis digunakan oleh anak SMA. Pendidikan SMA mempersiapkan peserta didik untuk belajar lebih lanjut di perguruan tinggi sedangkan pendidikan SMK mempersiapkan peserta didik untuk masuk ke dalam dunia kerja. Sehingga pembelajaran di SMA lebih mengarah pada teori sedangkan pembelajaran di SMK mengarah pada praktek.

Ketersediaan pengetahuan konseptual pada buku teks pelajaran I dan buku teks pelajaran II berada dalam kategori tinggi sedangkan ketersediaan pengetahuan prosedural pada buku teks pelajaran I dan buku teks pelajaran II berada dalam kategori rendah. Dengan demikian berdasarkan standar penilaian buku teks pelajaran yang dikeluarkan BSNP mengenai kelayakan isi, buku teks pelajaran I dan buku teks pelajaran II layak untuk digunakan karena perbedaan pengetahuan konseptual dan pengetahuan prosedural tidak signifikan. Keduanya sama-sama mengandung pengetahuan konseptual dan pengetahuan prosedural dengan jumlah memadai.

\section{Kesimpulan}

Berdasarkan hasil analisis data dan pembahasan hasil penelitian maka dapat disimpulkan sebagai berikut:

1. Ketersediaan pengetahuan konseptual pada buku teks pelajaran fisika kelas XII yang ditulis Kamajaya dan Purnama tahun 2016 pada materi pokok listrik dinamis sebesar $59,03 \%$ pada kategori tinggi dengan rincian sebagai berikut: pada bagian penjelasan sebesar $58,60 \%$, pada bagian kegiatan peserta didik sebesar $46,15 \%$, pada bagian contoh soal sebesar 52,63\%, dan pada bagian latihan soal sebesar $68,42 \%$. Sedangkan ketersediaan pengetahuan konseptual pada buku teks pelajaran fisika kelas XII yang ditulis Kanginan tahun 2018 pada materi pokok listrik dinamis sebesar $60,43 \%$ pada kategori tinggi dengan rincian sebagai berikut: pada bagian penjelasan sebesar $43,31 \%$, pada bagian kegiatan peserta didik sebesar $13,43 \%$, pada bagian contoh soal sebesar $88,89 \%$, 
dan pada bagian latihan soal sebesar 90,67\%.

2. Ketersediaan pengetahuan prosedural pada buku teks pelajaran fisika kelas XII yang ditulis Kamajaya dan Purnama tahun 2016 pada materi pokok listrik dinamis sebesar $13,89 \%$ pada kategori rendah dengan rincian sebagai berikut: pada bagian penjelasan sebesar 9,14\%, pada bagian kegiatan peserta didik sebesar $26,92 \%$, pada bagian contoh soal sebesar $47,37 \%$, dan pada latihan soal sebesar $12,28 \%$. Sedangkan ketersediaan pengetahuan prosedural pada buku teks pelajaran fisika kelas XII yang ditulis Kanginan tahun 2018 pada materi pokok listrik dinamis sebesar $15,75 \%$ pada kategori rendah dengan rincian sebagai berikut: pada bagian penjelasan sebesar $17,20 \%$, pada bagian kegiatan peserta didik sebesar $26,09 \%$, pada bagian contoh soal sebesar $50 \%$, dan pada bagian latihan soal sebesar $0 \%$.

\section{Saran}

Berdasarkan kesimpulan yang telah dipaparkan diatas, maka peneliti menyarankan beberapa hal sebagai berikut:

1. Pada penelitian selanjutnya peneliti lain dapat melakukan penelitian yang sama dengan menganalisis buku teks pelajaran fisika pada materi lainnya.

2. Pada penelitian selanjutnya dengan penelitian yang sama peneliti lain harus melakukan triangulasi pengamat pada data penelitian sehingga dapat mengurangi subjektivitas peneliti pada data penelitian.

3. Pada penelitian selanjutnya peneliti lain dapat menganalisis buku teks pelajaran fisika dengan mengembangkan aspek tinjauannya juga memasukkan pengetahuan faktual dan pengetahuan metakognitif. Karena pada penelitian ini terdapat $31,94 \%$ bagian yang tidak mengandung unsur pengetahuan konseptual dan proseduralpada buku teks pelajaran I dan $32,60 \%$ bagian yang tidak mengandung unsur pengetahuan konseptual dan proseduralpada buku teks pelajaran II.

4. Pada penelitian selanjutnya peneliti lain dapat mengembangkan penelitian untuk membuat bahan ajar fisika yang berbasis pengetahuan konseptual dan pengetahuan prosedural.

\section{Daftar Pustaka}

Druxes, H. (1986). Kompendium Didaktik Fisika. Terjemahan Soeparmo. Bandung: CV. Remadja Karya.

Iriani, F. (2016). Analisis Komparatif Buku teks pelajaran Fisika SMA/MA Ditinjau dari Keterampilan Generik Sains (KGS) pada Konsep Optik(Skripsi). Program Studi Pendidikan Fisika Universitas Islam Negeri Syarif Hidayatullah Jakarta . Kamajaya, K dan Purnama,W. (2016). Buku Siswa Aktif dan Kreatif Belajar Fisika untuk Sekolah Menengah Atas/Madrasah Aliyah Kelas XII Peminatan Matematika dan IlmuIlmu Alam. Bandung: Grafindo Media Pratama.

Kanginan, M. (2018). Fisika untuk SMA/MA Kelas XII. Jakarta: Erlangga.

Khamidah, L. (2017). Pemahaman Konseptual dan Pengetahuan Prosedural Siswa Kelas VIII dalam penyelesaian Soal Matematika Pada Materi Sistem Persamaan Linear Dua Variabel . Kediri: Jurnal Prosiding SI MaNis, 1(1).

Maturradiyah, N \& Rusilawati, A. (2015). Analisis Buku teks pelajaran Fisika SMA Kelas XII di Kabupaten Pati Berdasarkan Aspek Literasi Sains. Semarang: Unnes Physics Education Journal, 4 (1).

Pujiastuti, Indah. (2013). Analisis Kualitas Buku Pelajaran Bahasa Indonesia untuk Kelas Tinggi yang Digunakan di SD Negeri 2 Centre Curup Tahun Ajaran 2012/2013 (Tesis). Program Studi Pascasarjana Bahasa Indonesia Universitas Bengkulu.

Rahayu, W. (2017). Analisis Buku teks pelajaran Fisika SMA/MA Kelas XI Kurikulum 2013 Pada Konsep Gerak Harmonik Berdasarkan 
Aspek Keterampilan Proses Sains (KPS)(skripsi). Program Studi Pendidikan Fisika Universitas Islam Negeri Syarif Hidayatullah Jakarta . Respatiningrum, N Radiyono, $\mathrm{Y}$ dan Wiyono, E. (2015). Ánalisis Miskonsepsi Materi Fluida pada Buku teks pelajaran Fisika SMA. Surakarta. Jurnal Prosiding Seminar Nasional Fisika dan Pendidikan Fisika (SNFPF) Ke-6, 6 (1).

Sitepu, B. (2012). Penulisan Buku teks pelajaran Pelajaran, Bandung:PT. Remaja Rosdakarya. 